\title{
What can we learn from COVID-19 as a form of public pedagogy?
}

\section{Stefan Bengtsson}

Uppsala University, Sweden (stefan.bengtsson@edu.uu.se)

\section{Katrien Van Poeck}

Ghent University, Belgium (katrien.vanpoeck@ugent.be)

\begin{abstract}
This paper aims to investigate the corona-crisis as a large-scale, unplanned and unintended global experiment of 'public pedagogy'. An investigation is focused on touching upon emergent questions such as: What does our experience of the crisis brought about by the emergence of this specific virus tell us about our assumptions of learning and of public engagement with an issue as a form of public pedagogy? We bring into play transactional theory of teaching and learning, as well as Jan Masschelein's notion of pedagogical milieu of study and Timothy Morton's concept of hyperobject to conceptualize what we can learn from COVID-19 in terms of teaching and learning.
\end{abstract}

Keywords: Corona, hyperobject, public pedagogy, teaching, transactional didactic theory

\section{Introduction}

With the diffusion of COVID-19, we are facing a problem that suddenly and severely disturbs our customary ways of behaving. It calls into question many of our individual habits, but it also creates an impasse for a wide range of collective customs. The examples are countless. Schools close down as well as many working places, thereby disrupting the daily routines of the entire population. Our habitual ways of being mobile, consuming, washing hands, teaching, sneezing, spending the weekend, etc. are no longer possible or

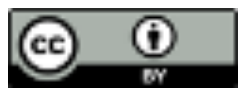


accepted. Hospitals have to adapt their way of working. Usual visits to loved ones are prohibited. As our changing environment increasingly emerges as a crisis that disturbs our habits, we are faced with the challenge of finding new ways of inhabiting the world. In such situations, 'learning' is often seen as a vital means to find a way out of the crisis. And indeed, every day we hear many people saying, for instance, 'that we should learn from what has happened in other countries' or that 'we will learn a lot from this' or that 'we need to learn to live together with the virus'. We also hear things such as 'this crisis will change us' and 'the world will no longer be the same afterward'. Accordingly, we as a public are turning towards 'learning' to make something out of the crisis we find ourselves in. What can we learn from the last couple of months for a future which we see as increasingly uncertain? What can we learn from COVID-19 as a form of public pedagogy?

This paper aims to investigate the Corona-crisis as a large-scale, unplanned and unintended global experiment of 'public pedagogy'. An investigation is focused on touching upon emergent questions rather than on providing or re-confirming existing notions of 'learning' and 'public pedagogy'. Accordingly, we engage with the question: What does our experience of the crisis brought about by the emergence of this specific virus tell us about our assumptions of learning and of public engagement with an issue as a form of public pedagogy?

Biesta (2012) argues for a conception of public pedagogy as the enactment of a concern for the public quality of human togetherness, giving shape to spaces and places that 'become public' and where freedom can appear. This is seen to involve educational work that supports the public quality of spaces and places and that is based on a degree strangeness rather than on commonality and common identity. In this paper, we investigate how the emergence of COVID-19 can be understood as something that calls into being a 'public of strangers' (Dewey, 1927) and how to understand this in terms of public pedagogy. Drawing on the insights of Dewey, Marres (2005, p. 47) explains how the specificity of the public rests on the particular way in which it is implicated in issues. In Dewey's account, a public consists of actors who are affected by particular actions or events while they do not have direct influence on them. As such, a public is caught up in assemblages of human and non-human actors that are already connecting people no matter how much they don't feel assembled by any common dome (Latour, 2005). The task of the public is thus, according to Marres $(2005$, p. 56), to take 'care of the serious trouble in which those who do not necessarily share a way of life are collectively implicated'. We will structure the infestation by framing the discussion of learning and teaching in the face of such problems by engaging with transactional didactical theory as well as bringing into play Jan Masschelein's notion of 'milieu of study' to conceptualize the public aspects of pedagogical engagement. In order to tease out the specific implications of the Coronavirus for our understanding of teaching and learning about it as part of a public pedagogy we will turn to Timothy Morton's notion of 'hyperobjects'.

\section{Positioning: Transactional didactic theory and the notion of 'environing'}

To ground our discussion of what we might 'learn' from the COVID-19 crisis, we turn to transactional theory of learning and teaching as it, at the core, emphasizes the educative potential of disturbances of habit and of business as usual. In this sense, it inspires us to conceive the massive disruption of habitual ways of being during the COVID-19 crisis as an opportunity for learning. 
Transactional theory of learning and teaching (Östman et al. 2019a, 2019b) is grounded in the work of John Dewey, in particular his writings on experience and education (Dewey, 1938) and the notion of 'transaction' he developed together with Bentley (Dewey \& Bentley, 1949). It perceives learning in terms of habit formation and transformation and as being triggered by the encounter of a problematic situation. Accordingly, an opportunity and need for learning emerges when habits become disturbed, that is when the learner encounters a problematic situation in which she cannot proceed habitually, applying, and committing to routine practices, knowledge, beliefs and values. Most of the time, people live their lives according to habituated ways of thinking and acting. The disturbance thereof induces an inquiry as a process guided by the need to reflexively engage with the situation leading up the disturbance as well as the quest for a way out of it. The disturbance is thus what makes us reflect.

An inquiry becomes necessary if we cannot easily overcome the disturbance of habit by slight modifications of our routine ways of doing and thinking. Such deeper disturbances of habits are problematic and present us with a crisis in the sense that cursory engagement with the disturbance does not immediately or easily allow for a reconciliation of habit and outcome. Instead, the disturbance emerges as a problematic situation that is not easily resolved but requires inquiry to create a refined or revised understanding of what the problem is and how it can be solved (Dewey, 1938). The concepts of problematic situation and inquiry have been used, for instance, to explain how students learn to understand scientific concepts, to gain insight in a language or to solve math exercises. In the case of COVID-19, however, we can say that the emergence and diffusion of the virus has caused a massive divergence of disruptions of habits. We are dealing here with a problematic situation that presents us with a macro-level crisis on a societal, even global scale. The required inquiry should therefore be conceptualized as a public inquiry that involves a collective, substantial transformation of habits through public experimentation with explanations of and solutions to problematic situations.

Before returning to what this could mean in terms of understanding COVID-19 as an experiment of public pedagogy, let's take a closer look at how habits, disturbances and inquiry are approached in transactional didactic theory (Östman et al., 2019a; 2019b). It understands a habit as a predisposition to think and act in a certain way in specific activities, which 'contains a specific way of coordinating with the surrounding world in relation to the purpose that governs the activity' (Östman et al., 2019a, p. 127). Further, a habit consists of two aspects: 1) a specific attentiveness and 2) coordination with the environment. To clarify, acting habitually is based on paying habitually attention towards particular objects in the world (cf., ibid) which inevitably involves neglect of other objects. Thus, the transactional didactic theory draws on Dewey's distinction between the concepts of 'environment' (those objects that are included in the attentiveness) and 'surroundings' (the totality of objects within reach in an activity) to introduce the dynamic, processual concept of 'environing'. Environing takes shape through the selection of some and neglection of other objects out of the surroundings, as the process of learning a habit involves to habitually learn to 'stage a relevant environment and to intellectually reason and bodily act in relation to that environment in such a way that certain outcomes are created' (ibid., p. 128).

Grasping COVID19 as a trigger for a public inquiry requires insight in the very specific process of environing taking place. After all, there is something strange in the way the emergence of the virus disrupts habits as it does so, for the most part, by an intermediary that is not part of any intentional act of environing but seems to unpredictably and uncontrollably influence habits and environments from the surrounding. Both the virus particle as well as the virus (Corona) its types (SARS-COV- 
2) and strains ( $\mathrm{S}$ and $\mathrm{L}$ so far) remain elusive and can only be adumbrated through technological means such as microscopes (individual particle) as well as statistical modelling and mass testing. It seems that the virus is not only disturbing, for example, habits of aviation, healthcare, education, production of consumer groups, harvesting of seasonal vegetables, etc., but also the very act of habitually constituting environments. We cannot directly see/know where it is and whether we are infected by it. And yet, as we know about its existence and potential presence, it affects our environing (e.g. making us more attentive to someone who is coughing) and the way in which we coordinate with our surroundings (e.g. keeping 1,5m distance from other people, redesigning public space). The impossibility to directly observe/experience and to fully know and control it as a specific object is not to deny that there is an object such as the SARS-COV2 virus particle. Rather, the point is that habits and processes of inquiry are disrupted by objects in the surroundings that are not fully present. The virus can be seen to assemble an audience, a public, for inquiry from the surroundings, disrupting the habitually created environment. What becomes apparent according to this outlook is that the virus assembles a public without the virus nor the public being fully present to one another. As such, because of the specific, mediated way to disrupt habits and the uncertainty, unpredictability, uncontrollability emerging from the fact that the virus also severely disrupts habits of inquiry which may lead to conspiracy theories, heated discussions, polarization, confusion, paralysation, etc.

Against the background of this strangeness of how the virus disrupts habits and assembles a public, we engage with the question how inquiry as a process of learning can be conceived given that we cannot fully know nor control the virus despite the urgency with which we have to respond to the disturbance as a problematic situation. Here we ask ourselves the question: Can COVID-19 teach us something about public pedagogy?

What is to be interrogated is how we can understand the role of the object of inquiry in public pedagogic forms, that assembles and disrupts environments as well as the habitual coordination of people and things. In order to do so, we will turn to Jan Masschelein's notion of 'milieu of study' to expand on the role of the object of attentiveness in public pedagogy and teaching

\section{Conceptual clarification: COVID-19 and Jan Masschelein's notion of 'milieu of study'}

The notion of milieu of study enables us to highlight how the act of environing can be further conceptualized in the context of COVID-19. Masschelein's notion of "milieu of study" is particularly appealing as it sees the milieu to be key to public pedagogic forms. It is in his understanding the fostering of particular milieus that associates or brings together the world and people, makes them meet and brings them into the company of each other (Masschelein, 2019, p. 189).

Teaching and learning as an act of environing can be seen as to foster particular milieus, where we might say particular sites are created. Masschelein (2019, p. 188) reminds us here that these 'sites' are real, yet they 'are at once heterotopic and heterochronic in Michel Foucault's sense: being a real place without place (in the regular social order, a lieu sans lieu), being real time out of (regular) time (temps hors temps)'. The act of environing or creating a milieu in this sense is 'not to represent the world, but to present it and to create temporal and sensorial conditions for studying the world, for giving form to "objects/subjects" of study'. (Masschelein, 2019, p. 189). We might be tempted to read this act of creating temporal and sensorial conditions in idealist terms, meaning that the world, objects and subjects are brought into being only by and in the act 
of giving forms by the teacher and students. Yet, we would like to propose a realist framing where it is in relation to unified, autonomous objects that milieus are brought into being (Harman, 2011). As Masschelein (ibid) highlights, the place of study is a gathering and assembly where one is to regard attentively and devote oneself to something. It is this something that brings about an 'us' (as a public) studying it carefully (with care and caring) and attentively as an object of study/inquiry. Thus, the creation of a milieu as environing can be seen as a regarding of something, where regarding as Masschelein highlights (ibid., p. 189) involves the consideration of something, paying attention to it and being concerned about it. Instead of being primarily about representation environing is about 'presentation', something is made present, presented to a public.

Interpreting Masschelein's remarks, this presentation of something in a milieu involves a spatial and temporal aspect. It creates an assembly (site/place -> spatiality) as well as a time (common disposition towards a future). To return to the concept of inquiry, this presentation is not so much about efficiently finding solutions to problematic situations in the sense of realizing predetermined outcomes but rather about how to proceed from a disruption, where that disruption is interpreted as being the result of something speaking. Interpreting something speaking, we argue, relates to the creativity required in the process of more substantial habit transformation or transgression that inquiry involves. What Masschelein is seen to offer is a conception of the source of creativity, that, as we earlier stated, can be seen to remain in the surroundings, and the pedagogic act of making it present.

The thing speaking, in our case COVID-19, can be seen to bring about a milieu, or it is environing in the sense that it bends and brings into being environments gathering assemblies (places), bending times, and shattering projected futures. Taking Masschelein's remarks on pedagogical milieu further we might here consider COVID-19 as to situate thinking. The virus forces us to become attentive not only to itself as calling into being an assembly but also to those other things and people in the assembly. In its disruptive capacity it can be seen to force us to try to think what we are seeing and not see what we are thinking (cf. Masschelein, 2019) in the ripple and cascade effects of the disruptions of habits in environments. Maybe the virus is 'teaching' us something in the sense that is making us attentive to our vulnerability (Bengtsson 2019). Vulnerability can here be understood as relating to a loss of imagined ability to control a milieu. Any thoughts that we are in control of the virus or have the ability to control it are disrupted as what we are seeing is not corresponding to this thought. As Masschelein (2019, p. 195) can be interpreted to suggest, COVID-19 can be seen as something that forces us as a public to undo our protection (déproteger), acknowledging that we are more disposed and exposed to that which becomes present in the milieu. To be exposed and to undo our protection entails, as Masschelein $(2019$, p. 196) highlights, a lack of intention as well as a suspension of judgement. This exposition is an act of attentive waiting, we might say an attentive waiting of an assembly.

If we then consider the implication of the milieu for a public pedagogy, the Coronavirus also highlights that attention and habitual attentiveness is not only about presences but also absences. Exposure and vulnerability highlight exactly the nonpermanence of things assembled. That something calling into presence a public as an assembly, speaks so to say also through absenting. Absenting of members of an assembled public by the Coronavirus might be one of the first things we paid attention to, such as the absence of traffic or airplanes in the sky. The portrayal of such disturbances and reconfigurations assemblies as problematic situations highlights an impossibility of retention given of an absenting. The special attentiveness that habit involves and the 
possibility of disruption of habit point here towards a particular aspect of attention to things becoming present again. Habitual coordination of environment implies here the retention of things partaking in transaction, yet projects also this retention towards that what we might call the present as a form of "protention" (Held, 2007), a projected expectation of things to take part (remain present) again. Disruption and attentiveness are in this sense highlighting the absenting aspect of being assembled in a public. COVID19 can be seen to be bending time and environments in the sense of disposing, dissolving and resolving milieus. The virus in this sense is bending the space of time (Zeitraum) of milieus, where Zeitraum in German refers to "location/duration" (a spatial construct of the time of something) and we might here speak of our location as public. In this sense the massive disruptions of habit caused by COVID-19 helps us to think that which we no longer see, as a form of special attentiveness towards things. It is also a thinking of a different "we" that is thinking, as the assembly is dis-located by the arrival of the virus. Thus, what we take as a core insight from our reading of Masschelein's notion of milieu is the attention for the importance of 'things' in processes and acts of environing. The latter, he shows, is not only relative to human habits and special attentiveness but it is also some-thing that brings the milieu into being, that assembles and disassembles a public in, or rather as, milieu. Furthermore, his emphasis on the pedagogical act of 'making things present' allows us to further conceptualize environing in a very specific, pedagogical way, i.e. as an act of organizing a specific attention to a thing, 'as lack of intention' and postponement of judgement.

It is here that we argue for moving beyond a mere process-oriented notion of environing and highlighting that a priori object or some-thing that precedes that process and at the same time is required for something to be made present. We turn here particularly to notion objects at play in the transactional notion of the process of environing that is involving an 'environment' (those objects that are included in the attentiveness) and 'surroundings' (the totality of objects within reach in an activity). In line with posthumanist approaches in education research we aim to account for objects and things as partaking in public pedagogy in a non-anthropocentric way, and to be specific to rethink how things are making themselves present without 'man being the measure of all things' (Snaza et al. 2014, p. 43). We turn here to an object-oriented perspective (Harman, 2011; Morton 2013) to account for how objects can be seen as to escape and disturb human efforts at environing, withdrawing and out of reach for activity and attentiveness yet still meddling with attentiveness and activity. Our object-oriented consideration of the Coronavirus is, hence, not concerned with the relationality of environment and surroundings as 'Corona' and its 'public' might emerge as part of practice and as a result of an 'agential cut' (Barad, 2007), but how humans/things/objects as members of a public are assembled by an imperative, yet, not fully present to another. Accordingly, to be in a and to engage with a public is not be in a relation but be a relatum confronted with the imperative of the public (cf. Harman, 2016).

\section{Conceptual clarification: The Coronavirus as 'hyperobject' partaking in a public pedagogy}

In the following we will turn to Morton's (2013) concept of hyperobject to conceptualize the specific status of COVID-19 as some-thing and how it assembles and appears to humans and other things partaking in an assembly. In particular we are going to explore how the characteristics of viscosity, non-locality, temporal undulation, phasing and 
interobjectivity of an hyperobject can be seen as to fit COVID-19 as indicative of the Coronavirus and what that means for engaging with it as part of a public pedagogy.

Viscosity relates to what Morton $(2013$, p. 27$)$ calls the menacing nearness and stickiness of hyperobjects, highlighting that we are caught up in them and that this nearness is challenging our self-perception as autonomous subjects unaffected by the surroundings. Corona as a SARS-COV2 virus particle and as COVID-19 highlights this nearness as it is both in us (particle) and we are caught up in it (Coronavirus family's genetic adaptation to Homo Sapiens as hosts). In this sense it troubles any understanding of surroundings and environment as if it would be two separate domains where an environment can be fully intentionally and controllably created out of the surroundings. In fact, as I cannot distance/isolate myself from the Coronavirus it is precisely menacing in the sense that it is too close. It is creating a milieu that is in this sense a non-place, where there are not distinct places, but an assembly that is too close for spatial differentiation. When Augé (1995, p. 103) speaks of the space as non-space neither creating singular identity nor relations; only solitude, and similitude, we can see how the Coronavirus is creating a milieu where we recognize ourselves as a public (similitude) in seeming solitude. In contrast to Augé's supermarket as the non-place of supermodernity, we might speak of the Coronavirus as the non-place of the Anthropocene. We find ourselves longing for the excesses of capitalist modernity captured and portrayed in Augé's supermarket, yet, confronted with the limitations and restraints imposed by government regulations on being in 'public spaces'. The residue of the virus haunting these 'public spaces' shows that they were not truly ours and that we, being in these spaces as public, were not alone (similitude). Accordingly, we might say that we see that the non-place of public space of supermodernity is caught up 'in' the Coronavirus as a Zeitraum (location/duration).

This relates clearly to the non-locality as a quality of the Coronavirus as a hyperobject. Morton (2013, p .47) highlights how hyperobjects cannot be understood as occupying a series of now points 'in' time or space but that they appear to be operating in a non-local and a-temporal sense. When we state above that we are caught up as an assembly in the Zeitraum of the Coronavirus we can read Morton's remarks on the nonlocality to highlight how COVID-19 is in the act of environing not graspable or coordinable as it eludes a directed attentiveness to it as an object. We might use a microscope to pay attention to a particular virus particle but the notion of having 'located' is simply an abstraction as COVID-19 cannot be located but only be adumbrated using statistical means and spatialization of data aggregates. In this sense, the Coronavirus as a hyperobject violates notions of boundaries and locality as it is ignoring national borders but also demarcations of entities. It twists the notion of locality at the heart of our understanding of learning as it is both inside the environing learner (here) and the learner finds itself 'in' it (the surrounding). What might be the most menacing and terrifying aspect of COVID-19 is, again, its viscosity, or the inability to extract ourselves from it. It is menacing as we cannot locate it/ourselves, isolate it spatially and temporally. Its nonlocality renders current attempts to coordinate with the environment through inquiry into the (spread of the) virus difficult. We might even say that it renders the idea of 'containment' of the virus problematic as containment hinges on the idea of being able to stabilizing locality as, literally, containment refers to keeping something within limits or in place.

The problematic aspect of the idea of containment relates to the fact that we cannot see the temporal and spatial beginning and end of the coronavirus as a hyperobject. When does COVID-19 end? Where is it? How can we know that it has truly ended or not being on the finger that I just put to my eye? When speaking of an end, we here speak of the 
possibility for humans to apprehend the coronavirus spatially and temporally. As of writing the virus is a 'current' pandemic (as ascribed to SARS-COV-2 as a current form of the Coronavirus) in a medical, global sense, yet, the Coronavirus as a family of viruses is suggested to have been there tens of millions of years (Wertheim et al., 2013), much longer than humans have existed. The Coronavirus is in this perspective so massive (both spatially and temporally) that it can be seen as to undulate time, or to put it into our previous phrasing it bends the Zeitraum (location/duration) of other objects caught up with it. Disruption of habits caused 'currently' by COVID-19 can, from the perspective of the history of the virus, be seen as limited temporal effect of the Coronavirus that has been there all along human history (ca 200.000 years) and for a much longer time before that (a number of millions of years before the emergence of the family of homo and later homo sapiens). Thus, the difficulty for understanding the 'time' of learning and teaching in the face of the virus is to not think time and space as a container in which COVID-19 and learning takes place but to see how COVID-19 is a temporal undulating effect of the Coronavirus, that disrupts the assembly of a public of things and people caught up with it. Think here of how the Coronavirus like a swinging giant spider at the centre of a spiderweb produces disturbances among objects caught in the web. Yet, this causality can as Morton be read to be suggesting to not be located in a past as relating to a human experience of temporality. Given its temporal scale, the Coronavirus as a hyperobject can be seen as to operate at a higher dimensional scale than human modes of experience. The virus can be seen as to stage a milieu or surrounding from this higher dimension, where it is emerging through disturbances of our habitual ways of attentiveness to objects and coordination with them. It does so from a scale which is not equivalent to human experience of the 'present' as it is not becoming 'present' as a presence in our present (referring here to the human experience of temporality), creating troubling consequences for inquiry.

The hyperobject as experienced in a milieu gives an imperative in the disruptions of habits to handle it, yet, we do not have 'time' to learn about them before handling them. We have to handle them despite a lack of time to learn about them. Morton (2013, p.67), borrowing a technical vocabulary from the visual arts, calls this effect 'temporal foreshortening'. As when drawing in a two-dimensional representation of something three dimensional, we can conceive of a pedagogical milieu as a temporal foreshortening, where a four-dimensional object is apprehended and regarded by a human being that only has access to three dimensions of its being. To use a parallel metaphor, think of public inquiry as an attempt at three-dimensional environing a tesseract utilizing a technique of temporal foreshortening. It is creating a (human) three-dimensional perspective, like a two-dimensional visual representation of a three-dimensional object, yet, this time doing so by representing a four-dimensional object as three-dimensional object from a limited three-dimensional anthropocentric perspective called 'now/here'. This human perspective is limited in the sense of regarding the hyperobject's spatially and temporally, even when utilizing theory and technology for accounting of the qualities of the objects beyond mere experience. Think here of how we speak of first, second, and, currently, third wave of the Coronavirus. The metaphorical depiction of a wave is exactly a form of temporal foreshortening in public inquiry into the virus. The undulation of the experience of the virus, that is its wavy form is, a result of its temporal foreshortening through inquiry. The increase and decrease of confirmed infections at a given date is appealing to a notion wave that is potentially still to come and beyond the temporal horizon of inquiry. Yet, inquiry is like foreshortening a technique and not actual representation of that something. For example, we do not assume the Corona virus to have ceased to exist in between waves or even before the outbreak of COVID-19. Accordingly, public inquiry 
into hyperobjects is forced to be adaptive to the temporal effects that are still to come and that cannot be captured in foreshortening through inquiry. Hence, in inquiry, the issue of 'imperative' is key, as such massively temporally distributed hyperobjects, as Morton (2013, p. 67) points out, exert downward causal pressure on shorter lived entities. Inquiry as a form of foreshortening does in this sense not end and there is the imperative for learning. We as humans find ourselves under the influence of massive objects that are not fully showing themselves. Yet, we find that these objects need to be addressed in what we call 'now'.

This influence, that is how these hyperobjects show themselves to us, can be described in terms of phasing. Morton (2013, p. 69) states that phasing is due to that hyperobjects occupy a high-dimensional phase space that makes them impossible to see as a whole on a regular three-dimensional human-scale basis. We only see glimpses of these objects (e.g. virus particles categorized as SARS-COV-2), where they (the Coronavirus) remain within a phase space. We might here think of the example of a two dimensional being (a flatlander) encountering a three-dimensional object, such as a cube, only seeing shifting formations of that object, while we as three-dimensional beings would recognize it as a cube given that we have access to the third dimension. A phase space describes here the set of all possible states of a system (Morton, 2013, p. 71). The non-locality of a hyperobject, such as the Coronavirus, is due to that it, in relation to human experience, is so spatially and temporally large that it produces phasing (from our perspective).

Phasing suggests a rethinking of the pedagogical milieu and acts of environing as discussed in the previous sections. Phasing highlights how a public as assembled by the hyperobject is not a public to be defined by a shared Zeitraum (locality/duration) but that the earlier discussed bending of this Zeitraum is due to for example the partaking of higher dimensional entities occupying a higher dimensional phase space. What is partaking in a transaction is, in this sense, not reducible to intentional attempts at environing through the retention of things in transaction as specific attention. Hyperobjects, such as the Coronavirus, seem to come and go, but this retention and absenting is only relative to the phasing effect on a human experiencing them. In a pedagogical milieu, the public assembled by the virus (the imperative) is a public potentially not fully bound together by the same Zeitraum. That is to say, the crisis or disruption of habit is not taking place at a given time as referential to an external universal notion of time and space, but the disruption of habit and Corona crisis can be seen to be due to the phasing effects of the Coronavirus as a hyperobject. It did not 'emerge', in this sense, but can be seen to have already been there as part of a milieu, in its phasing bending the retention of things in human habitual attentiveness in environing and, as such, appearing 'to us'. In this sense, the phasing of hyperobjects keeps habit, as a form of specific attentiveness, from environing the object. The hyperobject in its phasing is evading attentiveness as it does not become present as a visually directed presence (we are not able to locate it spatially nor temporally in experience). Regarding, in Masschelein's terms (2019, p. 189), refers to the consideration of something, paying attention to it and being concerned about it. In the context of our conception of the Coronavirus as a hyperobject, we might say that learning as a transformation of habit can be seen to be initiated when we direct our attention to how the assembly of things/people entangled with the virus is translating the virus. To regard the virus is an attempt to pay attention to how the virus is translated in the disturbance of transactions in the assembly. Thus, the focus is not so much on a regarding of presence, for example the virus particle in magnification under the microscope, but rather oriented towards the larger hyperobject located in phase space. The habit formation of specific attentiveness is in this sense different from organizing a 
predetermined attentiveness through direct observation and inquiry. It is not directed at environing objects from the surroundings given a projected Zeitraum, but to 'abstract' the virus as hyperobject without incorporating it into a Zeitraum. This involves a reversal of protention as a projected expectation of things to take part (remain present) again. Like the tesseract, the qualities of the Coronavirus have to be theoretically abstracted from disturbances in our experience. To utilize the spider web metaphor, the spider seems to be invisible, yet, we can become sensitive to its presence given our experience of disturbances in the net and other objects caught up in the net.

Being caught up in a net exemplifies the last discussed trait of the hyperobject, interobjectivity, where Morton highlights that the 'hyper-' of hyperobjects highlights something more general about what we might call the public or assembly in our discussion of public pedagogy. Morton's (2013, p. 86) point, as illustrated by hyperobjects such as the Coronavirus, is that it is not experienced directly but only through other entities in some shared sensual space. Accordingly, we might suggest that the 'public' in public pedagogy refers to this shared sensual space, and in that space assemblies are assembled by the imperative imposed by members/things. To utilize the notion of milieu, as provided by Masschelein, to characterize this public sensual space, we might conclude in the context of our discussion of the Coronavirus, that attentiveness to something presented to a public applied indirectly, that every act/process of environing is inevitably always only a presentation without full presence of thing presented/ing and the public. In the case of the hyperobject of the Coronavirus, that something presented is withdrawn and that the Coronavirus is only experienced in the form of a disruption of assembly or public.

\section{Conclusion}

If we are then to return to the question if COVID-19, and how we have approached it with the 'lenses' of Masschelein's 'milieu of study' and Morton's 'hyperobjects', can teach us something about public pedagogy - and, thus, teaching and learning - we believe that there are some crucial points to take into consideration in relation to the notions of 'environing' as well as 'inquiry' - two key elements of the above elaborated transactional didactical theory.

Against the background of our discussion of milieu of study and the virus as a hyperobject, we can now emphasize an understanding of 'environing' as a pedagogical act where things are made present ('presentation') in the full realization that there is always more than that which is/can be (directly) experienced and that this requires a specific attentiveness characterized by openness and precariousness. The way in which COVID-19 evades attentiveness as it does not become present directly highlights the importance of acknowledging that experiences of objects are not equivalent to or exhaustive of these objects. Due to its scale, being so spatially and temporally vast, the hyperobject of the coronavirus evades human experience. Environing - in line with a transactional perspective (Dewey \& Bentley, 1949) - should thus not be understood as a purely intentional process where people (pedagogues) can fully determine in advance which objects from the surroundings will be foregrounded as part of an environment and which will be absented and remain in the background. Instead, what COVID-19 shows us, is that hyperobjects are partakers in processes of environing. By doing so, objects in the foreground/surroundings can disturb any human intentional act of environing.

Further, the impossibility to directly and fully experience hyperobjects poses some vital didactic challenges. Realizing that there is something beyond human experience, 
after all, does not alter the fact that it is only through their experiences that humans have access to their surroundings. Furthermore, we all experience today how the virus' 'absenting presence' permeates and affects all our encounters. What does it then mean to didactically stage a 'relevant' environment if we cannot bodily act in relation to the object of concern, as the object can be seen to evade a direct relation to the learner's experience? What does it mean, for instance in terms of required trust in experts or technologies, that hyperobjects can only be 'made present' with the help of intermediaries/translation tools? Which problems are caused by the inevitable incompleteness of knowledge and the absence of full control?

There is thus to a certain extent a tension between, on the one hand, human experience - i.e. of a disturbance of habits that causes a problematic situation - as a starting point for understanding learning and, on the other, the role of (hyper)objects as partakers in environing processes that outrange human experience and intention. This challenge put forward by COVID-19 allows us to specify what it means to learn through 'inquiry' into problematic situations. First, we emphasize that a public pedagogy focused on (hyper)objects of concern like the Coronavirus but also, for instance, climate change, biodiversity, etc. requires a public inquiry.

The transactional theory of teaching and learning can also be used - and has been used - to analyse and describe the transfer of clear-cut knowledge such as how students come to grip with certain scientific concepts. Problematic situations investigated there are often (individually) experienced disturbances which make it impossible to immediately (habitually) answer a teacher's question, find the solutions for exercises, anticipate implications, etc. as the concepts are not (yet) intelligible. The teacher, then, can intentionally stage a fruitful environment in order to help the student's inquiry to result in making the concepts intelligible. Our discussion of COVID-19, however, sharply draws attention to the limits of well-planned and controlled teaching of well-known content. It shows, as argued above, that the object of teaching cannot be reduced to the teaching content as we cannot fully and directly experience what is 'present' through what is intentionally 'presented'.

Our discussion of COVID-19 as a hyperobject is by us seen as to provide entry points for conceiving the public aspects of staging the public aspect of 'fruitful' educative environments that are to address COVID-19 as a problematic situation. The public aspect of environing, as a pedagogical act, refers to the earlier mentioned openness and precariousness of the presentation and direction of attention.

Openness refers here to the openness of the Zeitraum of that which is to be presented and towards that which is to be included in attention. The notion of Zeitraum suggests here in German the notion of something bestehen (remaining) and geschehen (happening). The openness of environing is in this sense paying attention to geschehen (happening) that is related to the heterotopic and heterochronic aspect of staging environments as milieus of study. Letting objects of attention happen relates here to the publicness of the problem. The idea of paying attention to geschehen (things happening) can be seen to entail an active passivity that stands in contrast the idea of pre-determining, in advance, that which is environed and what that which is environed "is" as a content that is already contained. We argue the idea of existing in open view as central to the notion of public needs to be considering the viscosity of that openness, that is a threatening nearness of the public. Paying attention in the act of environing is as a passive activity also exposing and disposing the teacher and learner. It is in this exposition and disposition that we can open up towards that which is to be included in the act of environing. Letting things happen as disturbances or problematic situations is in this sense both metaphorically and literally contagious. Disturbances are contagious in the sense 
that they relate to the openness of the learner as a member of a public. The viscosity of COVID-19 is understood as to pull the individual experience of disturbance into the public given its exposure to it.

Precariousness refers here to the fruitfulness of learning that is taking place as a form of habit formation. Fruitfulness and its precariousness are here depending on the heterotopic and heterochronic aspects of staging environments as milieus of study. To clarify, we argue that when acting habitually we are not paying attention to neither objects nor ourselves. We are not 'aware' and not paying attention, or not attentive to what is happening (Geschehen). Accordingly, when acting habitually we are not engaging with the heterotopic and heterochronic possibility of environing. Learning as paying attention to disturbances, as a form of either voluntary or involuntary suspension of protention, is in this sense also opening up us to what is happening. To put it in the terminology of Masschelein, openness of awareness relates to the exposition of the experiencing learner and world so that we are exposed to the heterotopic and heterochronic aspects of the public. The educative relevance of this staging of environment is not reducible to a singular topos or chronos, but exactly to be found in the exposition to the heterogeneity of experience. This heterogeneity of experience is engaging with, what we have above called, the imperative of the public. Public inquiry into COVID-19 can accordingly be seen as to engage with staging of the heterogeneity of environing. The 'public' aspect of inquiry refers here to the imperative and consequent acknowledgement of unknown heterogeneity (precariousness), the avoidance of subsuming heterogeneity to, for example, scientifically derived homogeneity.

\section{References}

Augé, M. (1995). Non-places: Introduction to an anthropology of supermodernity. Verso.

Barad, K. (2007). Meeting the Universe Halfway: Quantum Physics and the Entanglement of Matter and Meaning. Duke University Press.

Bengtsson, S. L. (2019). A pedagogy of vulnerability. In J. Lysgaard Andreasen, S. L. Bengtsson, \& M. Hauberg-Lund Laugesen (Eds.), Dark Pedagogy: Education, Horror and the Anthropocene (pp. 143-158). Palgrave Macmillan.

Biesta, G. (2012). Becoming public: public pedagogy, citizenship and the public sphere. Social \& Cultural Geography 13(7), 683-697.

Dewey, J. (1927). The Public and Its Problems. Holt.

Dewey, J. (1938). Experience \& Education. Kappa Delta Pi.

Dewey, J., \& A. F. Bentley. (1949). Knowing and the Known. Beacon Press.

Harman, G. (2011). The Quadruple Object. Zero Books.

Harman, G. (2016). Barad's Entanglements and Transcontextual Habitats. Rhizomes:Cultural Studies in Emerging Knowledge, 30(30). https://doi.org/10.20415/rhiz/030.e13

Held, K. (2007). Phenomenology of 'authentic Time' in Husserl and Heidegger. International Journal of Philosophical Studies 15(3):327-47. doi: 10.1080/09672550701445191.

Latour, B. (2005) From realpolitik to dingpolitik or how to make things public. In B. Latour, \& P. Weibel (Eds.), Making things public. Atmospheres of democracy (pp. 4-31). Karlsruhe: MIT Press.

Marres, N. (2005). No issue, no public. Democratic deficits after the displacement of politics (Doctoral dissertation). University of Amsterdam, The Netherlands.

Masschelein, J. (2019). Turning a City into a Milieu of Study: University Pedagogy as 'Frontline.' Educational Theory 69(2):185-203. doi: 10.1111/edth.12365.

Morton, T. (2013). Hyperobjects: Philosophy and Ecology after the End of the World. University of Minnesota Press.

Snaza, N., Appelbaum, P., Bayne, S., Carlson, D., Morris, M., Rotas, N., Sandlin, J., Wallin, J., \& Weaver, J. (2014). Toward a Posthumanist Education. Journal of Curriculum Theorizing, 30(2), 39-55. 
Wertheim, J. O., Chu, D. K. W., Peiris, J. S. M., Kosakovsky Pond, S. L., \& Poon, L. L. M. (2013). A Case for the Ancient Origin of Coronaviruses. Journal of Virology, 87(12), 7039-7045. https://doi.org/10.1128/jvi.03273-12.

Östman, L., Van Poeck, K. and Öhman, J. (2019a). A Transactional Theory on Sustainability Learning" Pp. 127-139 in Sustainable Development Teaching: Ethical and Political Challenges, edited by K. Van Poeck, L. Östman, and J. Öhman, New York: Routledge.

Östman, L., Van Poeck, K. and Öhman, J. (2019b). A Transactional Theory on Sustainability Teaching: Teacher Moves" Pp. 140-152 in Sustainable Development Teaching: Ethical and Political Challenges, edited by K. Van Poeck, L. Östman, and J. Öhman, New York: Routledge. 